\title{
Role of Lithology and Rock Structure in Drainage Development in the Kaliani River Basin, Assam, India \\ Mukherjee, Sucheta and *Jha, V.C. \\ http://dx.doi.org/10.4314/ejesm.v4i2.7
}

\begin{abstract}
Lithology and Rock structure play a vital role in the development of Drainage Network in any drainage basin. The drainage patterns upon land surface develop as directed by the underlying lithology and rock structure. In fact, lithology and rock structure together shape the basin and are decisive parameters of nature and direction of channel flow. The Kaliani River Basin situated in Karbi Anglong district (Diphu subdivision), Assam State of India is strongly influenced by underlying lithology and rock structure. Tectonics play an important role, as the region has numerous minor lineaments and two major faults, and has undergone three phases of upliftment since late Cretaceous to late Miocene. The region is also influenced by neo-tectonics. The western and eastern parts of the basin are less influenced by structural lines of lithology while the northern and southern parts of the basin have fault-lines scarps and ridges. Trellised pattern of drainage is witnessed in most part of the basin which is made up of mostly Archaean gneiss and has developed along the lines of weakness with only some areas that have developed $a$ dendritic pattern due to flowing over softer rocks. The presence of a profusion of streams within the basin has given it a rugged surface and an intensely dissected terrain due vertical erosion of these young channels. An attempt has been made to analyse the role of lithology and rock structure in influencing the development of drainage network in the Kaliani River Basin. Basin morphometric techniques have also been applied for assessing the nature of the drainage lines in the study area. An attempt has also been made to find out the stages of geomorphic development of the Kaliani River and its major tributaries basins.
\end{abstract}

Keywords: Upliftment, neotectonics, lithology, antecedent drainage, dissected terrain, trellis,

\section{Introduction}

Water resources in any part of our world play a decisive role in determining the prosperity of banks any region and its people. Developed civilizations from ancient times have prospered along river by recognizing the immense scope offered by the rivers and harnessing its waters for a plethora of activities ranging from agriculture, transport, sports, personal hygiene, pisciculture, and at times for political boundaries as well. Some rivers though not very renowned in identity yet locally occupying prominence also play a significant role in some regions culturally as well economically on a micro scale. The potential resources of such rivers can be significantly exploited for local development and welfare shall be a significant task and basis for analysis of the physical nature of small rivers (Wadia, 1953; Baruah, 1997).

The Kaliani River flowing through the Karbi Anglong (Diphu subdivision) district of Assam, plays a significant role in the lives of the Karbis living along its banks. The river provides for the cheapest mode of transport after foot in an entire area where motorized transport is impossible due to the rugged nature of terrain. Though endowed with a rich stock of flora and fauna the region is completely inaccessible along its upper and middle course chiefly because the region lies over an intensely dissected Precambrian plateau.

Department of Geography, Visva Bharati, Santiniketan, West Bengal, India Corresponding author's e-mail:vcjha@asia.com 


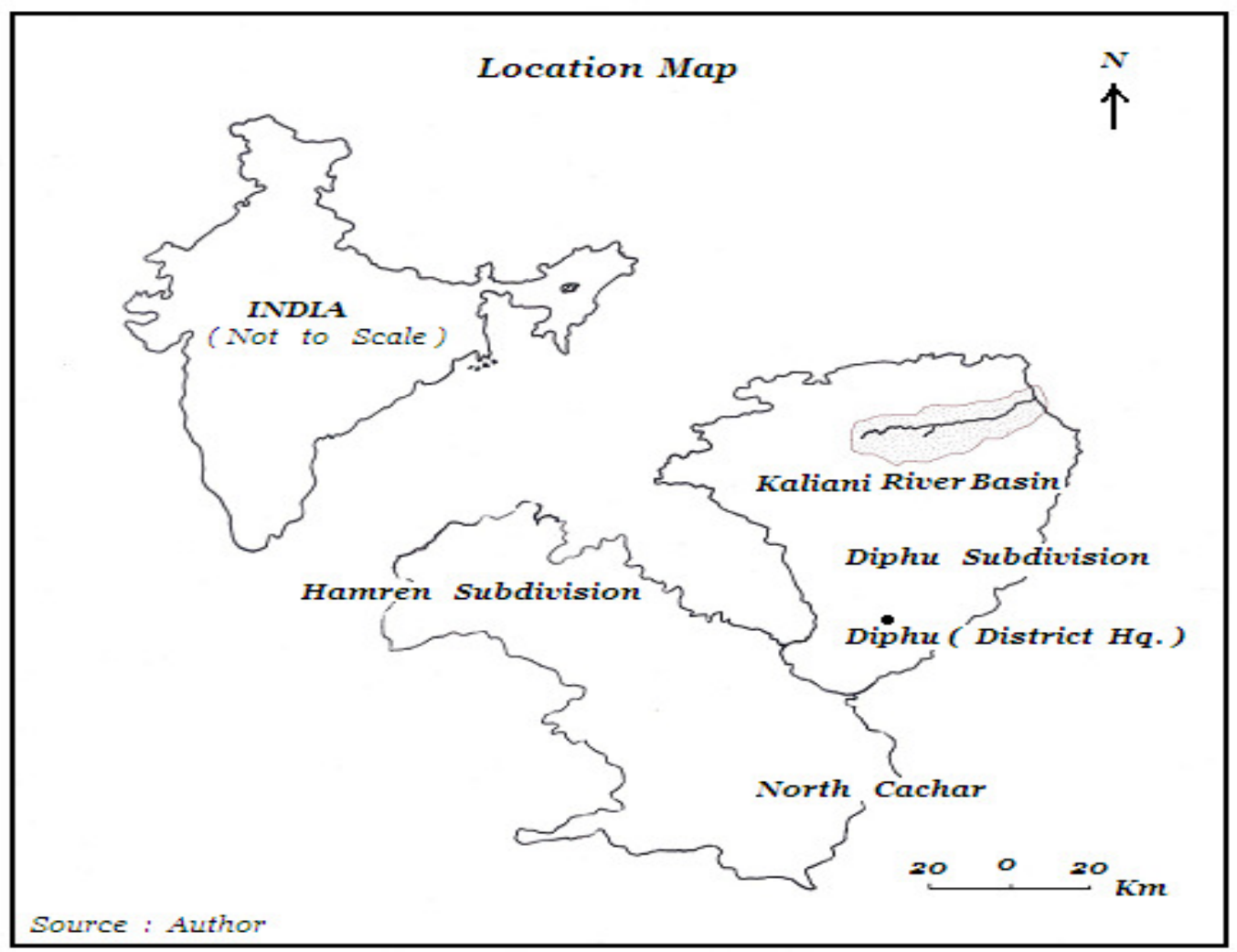

Fig. 1 Location map of the study area showing the district of Karbi Anglong (Assam) with its three subdivisions of Diphu, North Cachar and Hamren

\section{Methodology}

To identify the drainage patterns and analyse the influence of lithology and rock structures upon the drainage of the area, Remote Sensing, laboratory methods and field checks to obtain and compare ground truth were employed. In Remote Sensing technique, Image Enhancement technique (histogram equalization, linear stretching, trimming and standard deviation stretching) for better visualization and identification of the terrain units with the help of ERDAS IMAGINE 2009 was done. For identification of lineaments, various filters and karnels were used $(3 \times 3$ high pass filter, bilinear filters and directional filters) was used in ERDAS IMAGINE 2009. In GIS environment, georeferencing was done and 24 ground control points (GCPs) were taken for corresponding to the image with the toposheet.

In ArcGIS various layers of terrain units were prepared viz. rock unit (polygon), drainage layer (line), and settlement layer (point) for the preparation of DEM (Digital Elevation Model), contour layer was prepared. Collateral Data in the form of soil maps, Topographical sheets, extensive field checks and collection of rock samples and analysis and identification in laboratory were done and assimilated and later validated with the satellite imagery of the study area.

\section{Study Area}

The study area is located in northeast India, Assam between latitudes $26^{\circ} 13^{\prime} 47^{\prime \prime} \mathrm{N}$ to $26^{\circ} 40^{\prime} 38^{\prime \prime} \mathrm{N}$ and longitudes $93^{\circ} 12^{\prime} 38^{\prime \prime} \mathrm{E}$ to $93^{\circ} 48^{\prime} 36^{\prime \prime} \mathrm{E}$ (Fig.1). It is located to the south of the R. Bramhaputra and within the Mikir Hills. Reserved forest zone which accounts for the rich biodiversity of the area. The area can be accessed through the town of Golaghat in the East and through the district headquarter at Diphu to the southeast. The region experiences tropical monsoon type of climate with occasional thunder squalls preceding the monsoon months (June - August) and temperatures ranging from 
$5^{\circ} \mathrm{C}-38^{\circ} \mathrm{C}$ throughout the year. Winters are mild and foggy with scanty rainfall while summers are hot and sultry. The study area falls under seismic zone V of the Indian Seismicity Map which signifies a region of high damage risk zone or a region seismically active. The region is characterized by two very major faults and numerous minor faults which have been a significant factor in acting as controls and shaping the drainage pattern of the Kaliani River Basin.

\section{Aims and Objectives}

The study was under taken chiefly to ascertain

1. The role played by lithology and rock structure in controlling and shaping the drainage pattern of the Kaliani River Basin.

2. The stages of geomorphic development of the Kaliani River Basin.

3. The scope offered by the basin area for development and planning for civil purposes.

\section{Geological Background of the Study Area}

The study area is characterized by Precambrian rocks which are covered by those belonging to the Tertiary group. The Precambrian Basement complex represents part of the Gondwanaland crust of Proterozoic age in Assam (Kayal 1996,
Krishnan1953). Here Gneissic rocks of the Archaean group (oldest group of rocks) are found that occur with isolated patches of gneiss and Shillong group of rocks along the western margin of the basin (Smith 1898, Phangcho, 2001). The eastern part of the basin is covered by recent alluvium and laterite.

\section{Structural Background of the Study-Area}

The Kaliani River Basin area has been greatly influenced by the collision that took place during the Early Eocene between the Gondwanaland crust and Myanmar to the east and Tibet to the north. As this part of the land was caught up in between the collision zones of two landmasses all stages of collision tectonics took place thereafter (Vredenburg 1906, Nag 2003). The Mishmi Hills added a third compressional force from the northeast and subsequently a major uplift of the Shillong - Mikir Hills Plateaux also took place (DasGupta, 2000). This resulted in the folding; faulting and thrusting of the Precambrian basement and it subsequent uplift post-Eocene resulting in formation of multiple terraces (Nandy, 2001; Pirasteh, 2010). The sequence of geological events of Assam can be summarized as below (Table.1)

Table.1: Geological Formation in the Study-Area

\begin{tabular}{|c|c|}
\hline Recent & Young and Old Alluvium \\
\hline $\begin{array}{l}\text { Pleistocene } \\
\text { Pliocene } \\
\text { Miocene } \\
\text { Oligocene } \\
\text { Eocene } \\
\text { Cretaceous }\end{array}$ & $\begin{array}{l}\text { Sedimentation during the collision period with } \\
\text { several tectonic interruptions and depositional breaks } \\
\text { Sedimentation and carbonate formation, partly in the } \\
\text { collision zone and partly on the stable shelf. Some } \\
\text { igneous activity in the Cretaceous as reflected by } \\
\text { Sylhet Trap and other intrusives. }\end{array}$ \\
\hline $\begin{array}{l}\text { Gondwana Formation } \\
\text { (Permo - Carboniferous } \\
\text { to Jurassic ) }\end{array}$ & $\begin{array}{l}\text { Only a small development recorded from Assam proper, } \\
\text { but thicker development may be present in the basement } \\
\text { complex below the alluvial areas. }\end{array}$ \\
\hline $\begin{array}{l}\text { Pre Cambrian Basement } \\
\text { complex }\end{array}$ & $\begin{array}{l}\text { Representing a part of the Gondwanaland crust. } \\
\text { primarily of Proterozoic age in Assam }\end{array}$ \\
\hline
\end{tabular}

(DasGupta 2000) 


\section{Resultant Features of the Structural Controls in the Study Area}

Faults: The Kaliani River flows over fault aligned west to east and this accounts for the almost straight course of the river. The faults have led to displacement of rock strata as a result of strike and slip. The types identified in the study area are thrust faults, strike faults, normal faults and reverse faults (Thornbury 1954).

Lineaments: The lineaments in the study area though showing no displacement of rock beds are recent and most new tributaries to the trunk stream flow over them. The trend is west to east. There are about twelve lineaments and their alignment points to the fact that the forces of compression acted from the south of the study area.

Scarp: They are common in those regions which have undergone faulting. The southern part of the Kaliani River Basin has a steeper profile and the scarp acts as a water divide with the adjoining basin of Daigurung River. It is steep and erosion through time has given it a very rugged appearance.

Hogbacks: Variations in rock structure and rock resistance have led to erosion of exposed softer rocks while the hard metamorphics like granitoid gneiss have remained. The first order streams follow the syncline between the two ridges.

v) Monadocks: These features have formed as resistant rock masses offer greater resistance to erosion and have emerged where the surrounding softer lithological elements have been removed.

\section{Structurally controlled channels}

Rivers are generally controlled by lithology and rock structure and follow the general slope of the land. The Kaliani River and its tributaries in the study area have developed along the axes of syncline, folds and faults (Fig.2 and Table.2). There are multiple examples of stream piracy because of head ward erosion, sinous and narrow channels, river bending or forming a loop and flowing past monadocks. A total of eighteen tributary streams were selected for study in the basin area.

The hypsometric integrals of these channels reveal that about thirteen of the channels have attained maturity while five are still in their youth.
The Kaliani River has attained maturity (Fig.3). The five younger channels which flow over resistant rock cover, two of them are relatively straight streams flowing west to east over NS aligned lineaments namely Pora Jan and Deuri Nadi. The channels of Ar nam Langso, Langtangkang Langso and Bar Jan II are all flowing over gneissic layer superimposed by older alluvial cover, as the region over which they presently flow was once the fringe zone for marine sedimentation of the Tethyan sea when the Gondwanaland collided with northern landmass (Fig.4).

\section{Results and Discussions}

The existing geomorphology of the Kaliani River basin is the result of both; the endogenetic and the exogenetic processes. Although the basin iis also characterized by anthropogenic processes due to intensive agriculture and man-induced interferences. The Kaliani River Basin with an areal coverage of approximately $1200 \mathrm{Km}^{2}$ is an intensely dissected and rugged terrain. The drainage network of the basin has developed along lines of least resistance offered by the underlying rocks. Phases of upliftments have resulted in river rejuvenation from the knickpoints where the river has resumed its vertical erosion. It has scope for lateral erosion only in its lower reaches and the upper course where it is called the Phang Langso. The middle course is characterized by more resistant gneissic rocks and the channel narrows down as revealed by the NS longitudinal profiles. Resistance to erosion is high to moderate in regions of mechanically formed sedimentary rocks and metamorphics like gneiss. The lower reaches of the channel have deposits of laterite which date back to Quartenary period, on its banks which indicate degeneration of old rocks with the aid of moisture and points to the longer phase of stability of this particular part (Fig.3). The Kaliani River exhibits polycylic nature and the central portion of the basin is more rugged and immature as per topography. Drainage density is higher in the western and eastern part of the basin while low drainage density occurs where topography is steep in the central part of the basin. Due to hard bed rock over which the Kaliani River flows and it's relatively youthful to mature stage the river has not been able to deepen its channel. This results in 
floods during the monsoons as the channel is unable to carry the excess floodwaters and results in spilling over to the banks. Table 2 shows the existence of identified Drainage Patterns and their Geomorphic Characteristics in the Kaliani River Basin. It is evident that the major and minor faults, fractures, joints and rock foliations are responsible for the development of the existing drainage lines in the study area. The drainage system can be specifically termed as antecedent in nature because tectonics have played a decisive role besides lithology and rock structure in alignment of the major and minor channels. The presence of oxbow lake (Kaliani Beel) is an indication that the western and central part of the basin has undergone upliftment more recently than the eastern part near the plains of Golaghat.

Faulting and subsequent displacement of strata have exposed the coal bed over which the river flows and gives it, its characteristic black undertone and its name (in local language kali means black and pani means water hence the name Kaliani). Muscovite mica occurs in thin veins of pegmatite along with feldspar, tourmaline and glassy and smoky quartz in Naga Langso (tributary to R. Kaliani) and Mukjan hill areas along the Kaliani River. Thus, it is concluded that the kaliani River and its major tributaries are largely lithologically and structurally controlled in the study-area. The morphogenetic evidences are noted from Pre-cambrian to recent phases.

\section{Conclusion}

The Kaliani River flows over region which has limited scope for development due to the nature of the terrain. In some inaccessible regions villages like Baliram, Terrangaon and Khirangaon can be accessed only through the river and by climbing up the banks on foot. For road engineers this is indeed a challenge as the terrain is not similar to hilly one where the slopes can be cut to lay roads. On the other hand this remoteness has helped to preserve the biodiversity both in terms of flora and fauna. The lower reaches of the river are successfully used by the Karbis to cultivate ginger, pineapples, oranges, seasonal vegetables and paddy. Shifting cultivation is still prevalent and since the lower banks have laterite cover on the slopes, tea is also being cultivated which signifies a shift from traditionally preferred crops. The forested slopes are covered by bamboo and they are transported over the river as rafts, downstream to the nearest market. Hard granite and gneiss found in the region can be used as stone chips or for paving roads but inaccessibility is a major problem. Thus, it is the nature endowed topography of this particular region which makes it so remote and protected from large scale commercial use.

\section{References}

Baruah, S. (1997), Pattern of Seismicity in Shillong Mikir Plateau and the orientation of compressional axis. Jour. Geol. Soc.India, 49, 533 - 538.

DasGupta, A.B. (2000), Geology of Assam, Geological Society of India , Bangalore pp 11-20 and 96-107.

Kayal, J.R. (1996), Earthquake Source Processes in Northeast India: A review. Him. Geol., 17, 53-69.

Krishnan, M.S. (1953), The Structure and Tectonic History of India. Jour. G.S.I. Kolkata, 81, 1 - 37.

Nag, S.K. ( 2003 ), Influence of Rock Structures in the Development of Drainage Network in Hard Rock Area . Jour. Photonirvachak, Indian Society of Remote Sensing, 31(1), 1-2.

Nandy, D.R. (2001), Geodynamics of the North-East India and the Adjoining Region, pp. 111 - 138 Nandy, D.R. (1981), Tectonic Pattern in NE India a discussion. Indian Jour. Earth Sc., .8(1), 82- 86.

Pirasteh, S. (2010), Litho-morphotectonic analysis using Landsat ETM data and GIS techniques: Zagros Fold Belt (ZFB), S.W Iran. Jour. International Geoinformatics Research and Development, 1(2), 19.

Phangcho, P. C. (2001), Karbi Anglong and North Cachar Hills: A study on geography and culture. Printwell Publishers, Diphu. pp. 1- 56.

Roy P.S. (2010), Remote Sensing Applications, NRSC, Hyderabad, pp 165-178.

Smith, F.H. (1898), The Geology of Mikir Hills in Assam. Jour. GSI Kolkata, 28 (1) 1 - 11.

Thornbury , W. D. (1954), Principles of Geomorphology. Wiley, pp. 139 - 161.

Vredenburg, E. (1906), Pleistocene Movement in Indian Peninsula. Jour. G.S.I. Kolkata, 33(1), 1- 69

Wadia, D. N. (1953), Geology of India. Macmillan; New York: St Martin's Press. 552pp. 


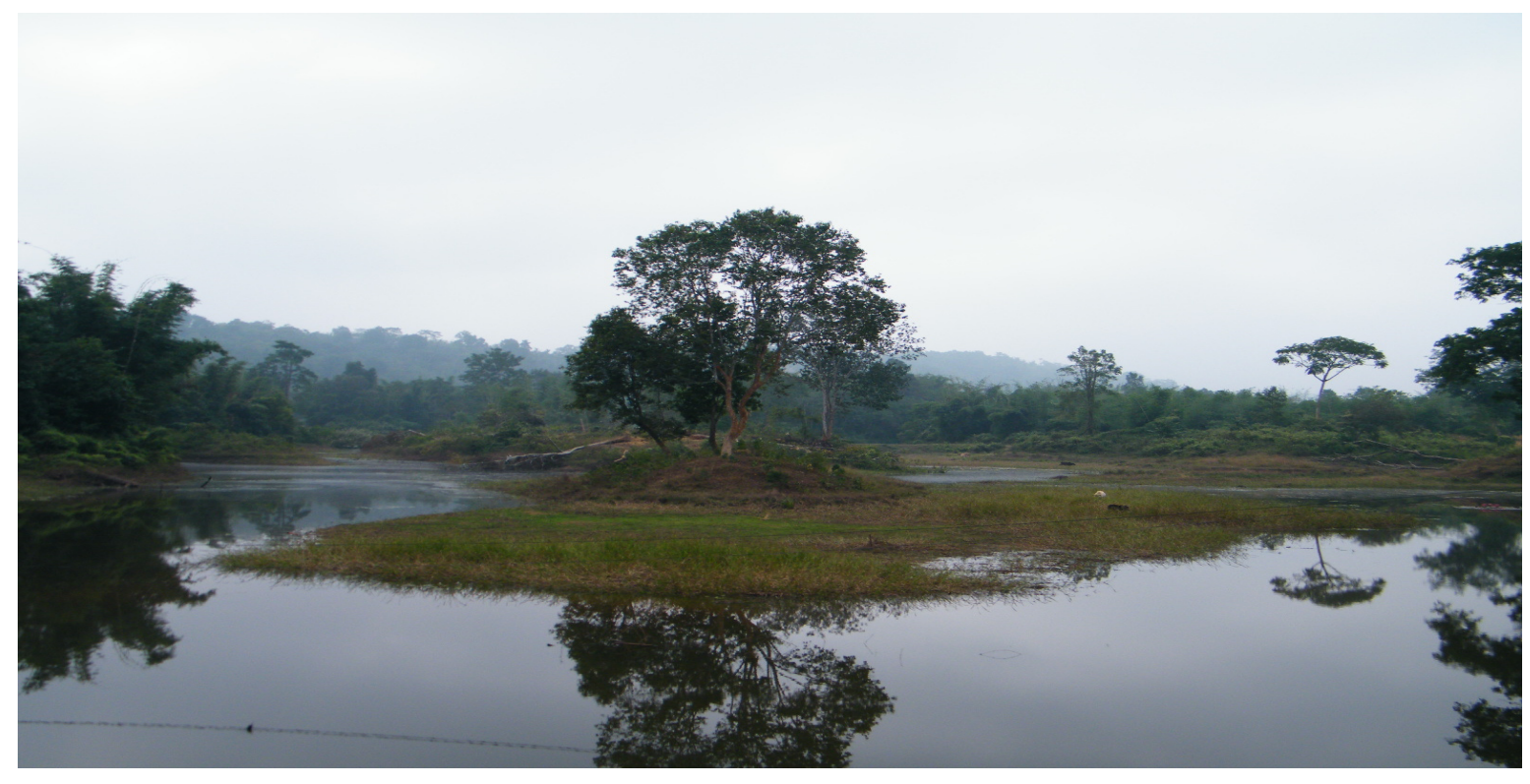

Fig.2 The river bends around a resistant mound of gneissic rock near Tuchagaon

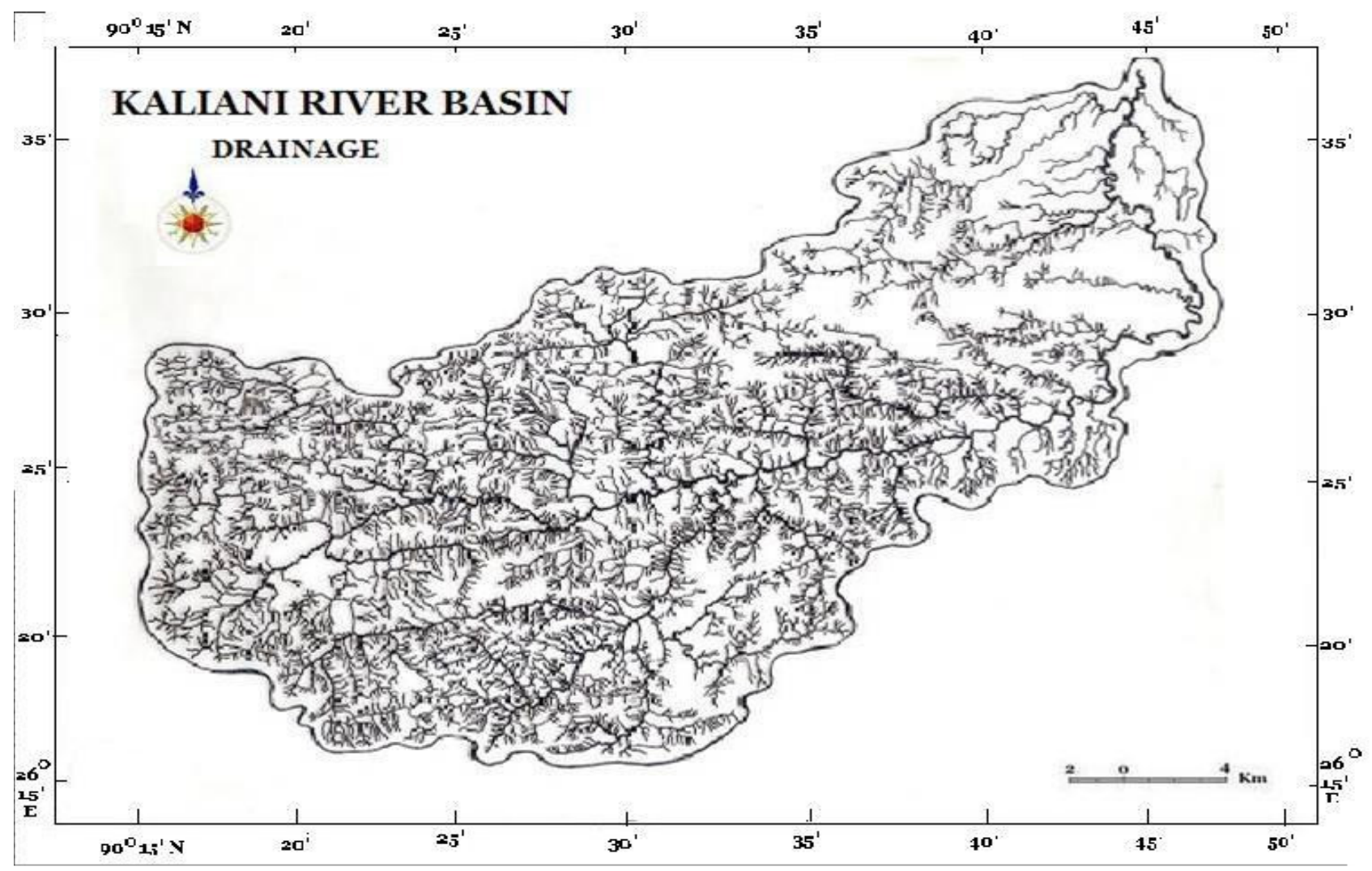

Fig 3.The Drainage Basin of the Kaliani River 


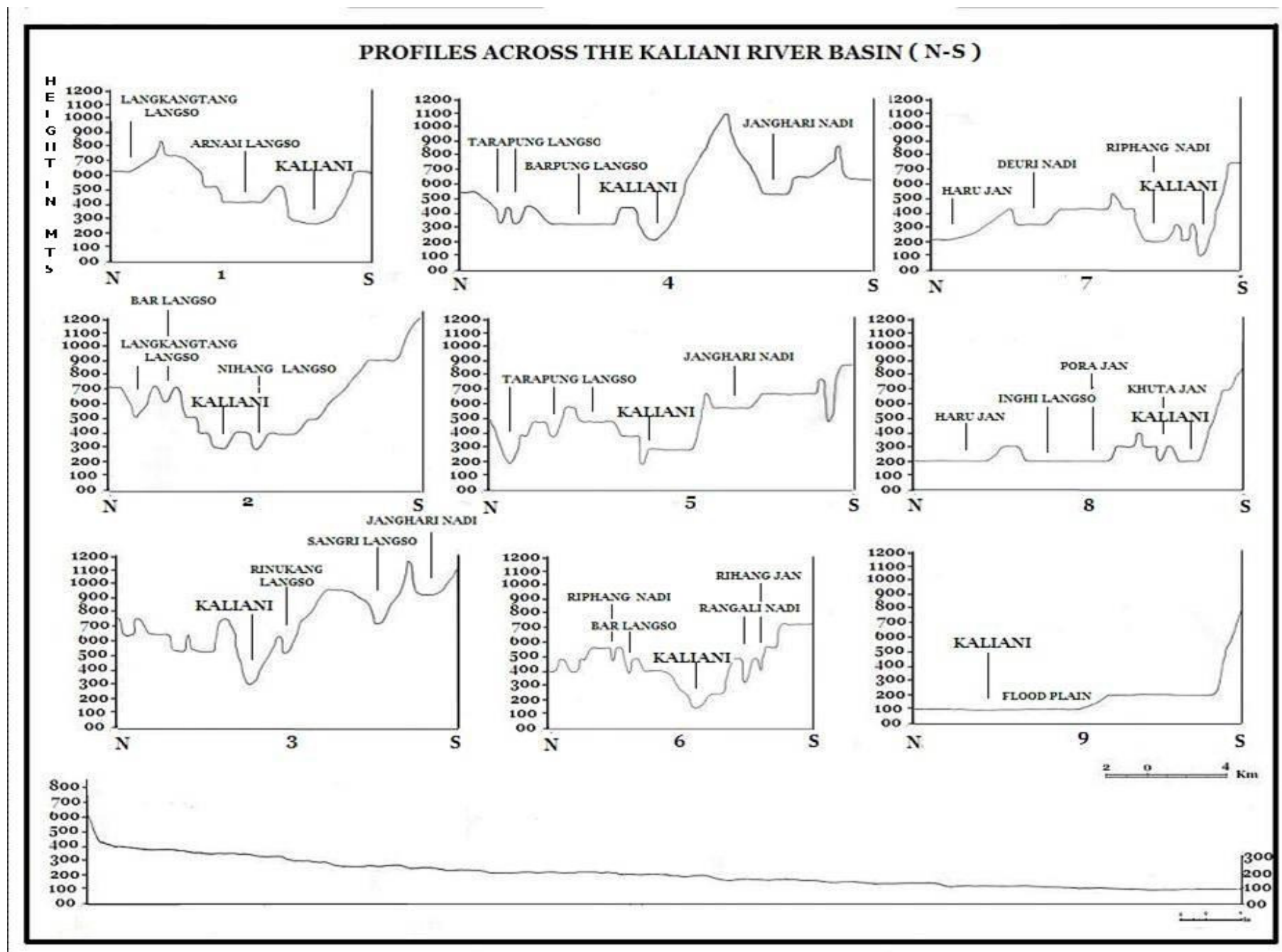

Fig .4 the N S cross profile of the river reveals the ruggedness of the terrain 
Table.2: Identification of Drainage Patterns and their Geomorphic Characteristics in the Study Area

\begin{tabular}{|c|c|c|}
\hline S.N. & Drainage Pattern & Geological Significance \\
\hline & Dendritic & $\begin{array}{l}\text { Develops in region of rock homogeneity, show lack of structural } \\
\text { control; indicates horizontal to sub horizontal bedding and gentle } \\
\text { regional slope. Eg. Shales and granitic gneiss. Found in the tributary } \\
\text { basin of Jhanganri Nadi located on the right bank. }\end{array}$ \\
\hline & Rectangular & $\begin{array}{l}\text { Shows structural control develops along joints/faulty intersections at } \\
\text { right angles. E.g. sandstone found in the tributary basin of Barpung } \\
\text { Langso where the first order tributaries are trellised located on the left } \\
\text { bank. }\end{array}$ \\
\hline & Trellis & $\begin{array}{l}\text { Shows structural control; develops in areas having parallel } \\
\text { fractures/faults. Tilted interbedded sedimentary rocks having } \\
\text { differences in rock resistance. Folded sedimentary sequence found in } \\
\text { the tributary basins of Nihang Langso Rinukang Langso on the right } \\
\text { bank and Langkangtang Langso and Barpung Langso on the left bank. }\end{array}$ \\
\hline & Parallel & $\begin{array}{l}\text { Develops due to pronounced regional slope or in areas having elongated } \\
\text { geomorphic features such as homoclinal ridges of quartzites. Found in } \\
\text { the basins of Sangri Langso (right bank), first order streams of } \\
\text { Jhanganri Nadi (right bank) in its middle course, first order streams of } \\
\text { Phang Langso and Barpung Langso (left bank). }\end{array}$ \\
\hline & Radial & $\begin{array}{l}\text { Associated with domes, doubly plunging folds, volcanoes etc. Found at } \\
\text { Inglang Ikpi (1281m) and Warekmushak Anglang (1049 m) on the right } \\
\text { bank. At Hijung Langri Anglang ( } 891 \mathrm{~m}) \text {, Haru Lauri Anglang (727 } \\
\text { m), Inglang Klampi (756 m), Thiesibi Anglang ( } 855 \mathrm{~m}) \text {, Inglang } \\
\text { Mangho (682 m) and Khelebishon ( } 886 \mathrm{~m}) \text { on the left bank. }\end{array}$ \\
\hline & Deranged & $\begin{array}{l}\text { Indicates limestones in humid topography found in the flat area where } \\
\text { the river is called Langlakso Nadi on the left bank. }\end{array}$ \\
\hline
\end{tabular}

(Source: Roy, 2010) 